\title{
Sari-The Most Draping Attire Of Indian Sub Continental Women: A Critical Study
}

\author{
${ }^{1}$ Najmul Kadir Kaikobad, ${ }^{2}$ Farhana Sultana, ${ }^{3}$ Afroza Huq Daizy, \\ ${ }^{4}$ Md. Mehadi Hasan Khan \\ ${ }^{I}$ Assistant Dean \& Assistant Professor, Department of Fashion Design \& Technology, Shanto-Mariam \\ University of Creative Technology, Dhaka, Bangladesh \\ ${ }^{2}$ Assistant Professor, Department of Fashion Design \& Technology, Shanto-Mariam University of Creative \\ Technology, Dhaka, Bangladesh \\ ${ }^{3}$ Lecturer \& Coordinator, Department of Fashion Design \& Technology, Shanto-Mariam University of Creative \\ Technology, Dhaka, Bangladesh \\ ${ }^{4}$ Lecturer, Fundamental of Art \& Design, Shanto-Mariam University of Creative Technology, Dhaka, \\ Bangladesh
}

\begin{abstract}
Sari, by name it is a dress of women of India, Bangladesh and Sri Lanka. Though there are many debates about the inceptions of sari, Indian Subcontinent is the birth place of sari. Interestingly the attire sari was used men and women in the many parts of the world for its prestigious application, still now it remain same with the women world whenever men has cut it off questioning gender issue. Its decoration, embellishment and application have changed but use and acceptability of the society is still same. It's just for the appeal of the sari as the most beautiful dress in the world. It is the dress for casual, formal, party, leisure, eventual and romanticism. It is the dress from corner of the village to the flush lighted metropolitan. It is dress for the every walk of life to the formal outfit of the prime minister. It is dress for all age and all events from home to work, casual to party hot to cold seasons. Its styling of wearing has a significant role creating variation of expose, in fact which makes the scope of sustainability of choice.
\end{abstract}

\section{Glossary:}

Belawadi Mallamma: Character of the Vedas, who fought for Jhansi Queen Laxmibai

Kittur Chennamma: Character of the Vedas, who fought for Jhansi Queen Laxmibai

Prakrit: The root of Sanskrit words

Lungi: Men's wear used by male person in Bangladesh, Myanmar, India and Sri Lanka

Shawl: a piece of clothing worn for winter fashion

Ghagra: A skirt type of dress worn by Indian women

Petticoat: A skirt type of dress worn as under garment with sari

Graeco or Greco: Roman scholar style

Gandharan: Ancient civilization of Buddha

Holi: A religious festival of Hindu

Diwali: A religious festival of Hindu

Dussehra: The final day of Durga puja

Lohri: Religious festival of Punjab people, India

Baisakhi: The first day of Bangle year

\section{Introduction:}

Sharee or Sari is the most magnificent draping art of the world, which has an elegant history from its inception to the modern time. Sari is worn by millions of Indian Subcontinent and Bangladeshi women and is, by far the most elegant. It is not merely an outfit but a living art or an ornament, lending both grace and glamour to the wearer. More importantly, the sari exemplifies the continuity of an age-old tradition that has been survived the onslaught of many different cultures, to emerge today as a visible symbol of the resiliency, continuity and timelessness of the Indian Subcontinent way of life.

The sari speaks for itself of so many things. Every rustle of this unique garment has a story to tell stories both of happiness and of sorrow. For the sari has seen it all. It has shared, with the wearer, every gradation of human experience - the joy and happiness of marriage, as well as the sorrow of parting, the pleasures and satisfaction of motherhood, the happy times when the life dealt kindly, the trying times when adversity was met with typical Indian Subcontinent stoicism. 
A nine yard sari used to be a connoisseurs pleasure with embellishments, embroidery and gold design. At the same time it was as safe a dress as trousers. It was worn in the same manner as working sari. But some doctors also covered the ankles. A gold silver or cloth belt was fastened which kept Pallu, (upper cover) and put folds intact. Jhansi's Queen Laxmibai, Belawadi Mallamma and Kittur Chennamma fought enemy troops on horseback, wearing sari this way. Tight you eat of the foremost place in the back was called Veeragacche or soldier's tuck. Raja Ravi Varma, the distinguished painter of the 19th century, toured the entire sub-continent to find the ideal woman-wear. He wanted the best dress for the various goddesses he was asked and commissioned to paint. He chose one nine yards sari which drapes the body beautifully at the same time exhibiting contours of female anatomy - bust, waist, hips. Most of the female deities he painted are in this style. The mood, the occasion; the event can all be conveyed through the sari. The color reflects the occasion. The way it is draped signals the community. Brocades speak of happy times, an event of celebration - the birth of a baby, the marriage of a dear one. Festivals life Diwali or Durga Puja, are occasion to bring out colorful dreams in gold woven in-between vibrant rainbow-hued skeins of silk. Solemn white speaks of death, of the parting of a loved one. For those in the immediate family it indicates a state of mourning and for those who come to offer condolences it is a sign of their empathy with the bereaved.

Besides, the sari is universal. Grandmother and grand daughter can both carry off the same sari with equal grace. It moulds itself easily to every circumstance. No matter, how convenient, other Indian Subcontinent costumes may be, it is extremely unlikely that any women will give up wearing sari.

\subsection{History and Origin of Sari:}

\section{Literature Review:}

Sari is the most sensual attires of a woman in Indian Subcontinent and Bangladesh and Sri Lanka. It is along unstitched piece of cloth with marvelous surface decoration, usually 4.5-5.5 meters long that is draped in a set pattern. It emphasizes the curves of a woman and the mid-riff is usually exposed by its art of wearing called draping. However, the way of draping a Sari may differ from place to place. The way it is draped in the north may be slightly different from how it is draped in the south. It is available in a plethora of fibers, designs and colors. The sari is usually worn with a blouse (Choli in Hindi) that covers the upper part of the body and underneath it is the petticoat (Chhaya in Bangla), which helps to tuck in the pleats of the Sari to hold it in place. Sari has an age old history since its inception in the Indian Subcontinent. Its inception is somewhat mingled with history of civilization. Substantiation states that women in the Indus Valley civilization used to cover themselves with a long piece of cloth, draped like a trouser. However, the word 'sari' originated from the Prakrit word 'sattika', which is mentioned in the early Buddhist literature. The word got shortened and was called 'sati', which further evolved into sari. A statue recovered from the Indus Valley Civilization depicts a female priest wearing a cloth draped like a sari. The sari used to be draped in a way so that it divides the two legs and forms a trouser like attire. This was basically done to aid the temple dancers in their movements and also covered to their modesty. It is believed that the 'dhoti', which is the oldest Indian Subcontinent garment that was draped, is the foundation behind the sari. Till the $14^{\text {th }}$ century, the dhoti was worn by both men and women in Indian Subcontinent.

The early statues of Goddesses show that the sari was draped in a sensual manner, like a 'fishtail', which was tied at the waist, covered up the legs and came in front of the legs like a decorative drape. During that era, the upper part of the body was either partially covered or was left bare. Down south in the state of Kerala, one can still see people wearing the traditional sari, which is a two piece garment, consisting of a lungi and a shawl. With the coming of the Muslims, the 'ghagra' or the 'petticoat' was discovered and clothes were stitched. Before that, Hindus believed piercing clothes with needles was impure (Peter MacCloud, 2006).

The blouse came into existence with the Muslims and also the British. Since then, sari has come of age and now many new styles are being experimented with. But the main aspects of the sari like the blouse and the petticoat have been carried over in the modern times. Thus, sari is the perfect garment to enhance the beautiful curves of the Indian Subcontinent woman and has done so since times immemorial.

Men and women continued to wear three unstitched garments, as in the Vedic times. The main garment was the Antariya of white cotton, linen or flowered muslin, sometimes embroidered in gold and precious stones. For men, it was an unstitched length of cloth draped around the hips and between the legs in the kachcha style, extending from the waist to the calf or ankles or worn even shorter by peasants and commoners. The Antariya was secured at the waist by a Sash or Kayabandh, often tied in a looped knot at the center front of the waist. The Kayabandh could be simple Sash, Vethaka; one with drum-headed knot at the ends, muraja; a very elaborate band of embroidery, flat and ribbon-shaped, Pattika; or a many-stringed one, Kalabuka. The third item of clothing called Uttariya was another length of material, usually fine cotton, very rarely silk, which was utilized as a long scarf to drape the top half of the body.

Saris origins are obscure, in part because there are so few historical records in Indian Subcontinent. Yet, we know that Indian Subcontinent was wearing unstitched lengths of cloth draped around their bodies long 
before tailored cloths arrived. One of the earliest depictions of a Sari-like drape covering the entire body dates back to 100 B.C. A North-Indian Subcontinent Terracotta depicts a woman wearing a Sari wound tightly around her entire body in the trouser style. This elaborate body-hugging style represented in the terracotta may have evolved among Indian Subcontinent's temple dancers in ancient times to allow their limbs freedom of movement while at the same time maintaining their standards of modesty. There are many sculptures of Graeco-Indian Subcontinent Gandharan civilization which show a variety of different Sari draping styles. Tailored clothes arrived in Indian Subcontinent with the arrival of Muslims. Hindus believed that any cloth pierced by needles was impure.

It is commonly believed in Indian Subcontinent that today's petticoat or 'Ghagra' and the blouse or 'Choli' which are worn under the Sari are later additions which started with the coming of British in Indian Subcontinent. Increasing number of upper class women in the early 20th century did adopt items of European style clothing as the fitted blouse and slim petticoat. This was also adopted due to the fashion of transparent chiffon Saris during that particular period. Some of the wives of Indian Subcontinent Kings draped themselves in Saris that were made by Parisian designers.

The concept of beauty in ancient Indian Subcontinent was that of small waist and large bust and hips, as is evident in the sculptures of those times. And Sari seemed to be the perfect dress to flaunt those proportions as it exposes the waist of a woman and emphasizes the waist and bust with the pleated fabric. Sometimes women wore accessories like girdle (a belt) with elaborate design around their waist to emphasize the hip area.

In the virtuous triumphed in Indian Subcontinent in around this 3000 BC, old Indian Subcontinent epic; Mahabharata is the first recorded reference to lasting attractive SARI - the longest, most popular style in the history of women's fashions. The artisans make cotton thread high-reeling and weaving cloth. The method of dying is practiced by making vegetable dyes from locally available plants mainly of katha color. The limit of Saris and motifs are woven with colorful thread, which is colored by the local method. The clothes are very durable and motifs are peculiar.

Sari is as old as civilization in Indian Subcontinent. Known records are date back to at least before Christ. Cotton is grown and woven into the fabric in Indian Subcontinent five thousand years ago. The concept of beauty in ancient Indian Subcontinent was that small waist and large bust and hips, as is evident in the sculptures of these times. Sari seemed to be the perfect dress to flaunt those elements which exposes the life of a woman, and emphasizes the waist and bust with the pleated fabric. Sometimes, women wore accessories like girdle (belt) to develop design around the waist to emphasize the hip area.

The Indian Subcontinent Sari boasts oldest existence in the sartorial world. It is more than 5000 years old! It is mentioned in the Vedas, the oldest existing (surviving) literature (3000 BC) Patterns of dress change throughout the world now and then, but Sari has survived because it is the greatest wear and tear of rural Indian Subcontinent. $75 \%$ of the population (now 1.3 billion per official estimate) wear versatile sari. We can certainly call this cloth versatile because it could be worn as shorts, trousers, flowing gown-like or practical skirt-wise all without a single nail!

Sari (original - Chira in Sanskrit, cloth) is of variable length. From 5 yards to 9.5 yards tied loosely, folded and pleated, could be turned into working dress or party-wear with manual skill. For day today dress of middle class women, 5-6 yard sari is comfortable to manage household chores. Working class puts the same length above the ankles, and if they will work in water or fields, they would tuck the front lay between his legs on his back and tie the top around the waist. This left them free hands and legs.

\subsection{Sari in different ages:}

The 1st century AD saw the Sari in its earliest form. It was a brief garment with a veil. A well-known Indian Subcontinent painter of the 19thcentury was asked to paint various goddesses. For this purpose, he looked for a wear, which suited the goddesses he was to paint. He scouted the length and breadth of the subcontinent for that perfect female-wear and he found one, in the form of Sari, a garment that in his opinion was made for a perfect female wear. It fitted and presented a woman, as they should be.

History too tells us that famous Indian Subcontinent historical battles fought by the heroines like Queen Jhansi Laxmibai, Belawadi Mallamma and Kittur Chennamma wore Sari during their battles. Neatly and tightly tucked away between the legs, the Sari enabled them to battle enemy troops on horseback. These Saris were longer in length than the regular ones and worn like Dhoti, wrapped around in total grace and elegance.

Sari, the world's oldest surviving garment, is still de rigueur outfit for most brides. Indian Subcontinent marriages showcase our ancient rich heritage in the form of Sari draped by brides from different regions. Even colors and patterns woven in various fabrics of Sari, signify many beliefs embedded in our culture. The bride's charm heightens more in a beautiful Sari. There are varied ranges to choose from. Like Mysore silks, Banarsis, Kanjivarams, Paithanis, Pochampallis, Patolas, Tanchois, Tangails, Jamawars, Balucharis, Zardosis, Gharcholas, those embellished with rich gold and silver embroidery, mirrors, crystals and beads to designer saris. 


\section{3: Sari in the $20^{\text {th }}$ Century:}

Indian Subcontinent culture and tradition is rich and vast. Indian Subcontinent cultural traces have been found age old practice of wearing sari. Dressing is one of the most highlighting elements of the Indian Subcontinent culture. Indian Subcontinent dresses in the post-Independence era mainly consist of sari and other traditional clothes. After the independence of Indian Subcontinent and mainly in the last decade of the 20th century there were major changes noticed in the way Indian Subcontinent women dressing. With the effect of globalization and other factors, ethnic and traditional Indian Subcontinent women clothing was combined with the Western fashion to give a special touch to the clothes. The fashion industry like in all parts of the globe is ever changing in Indian Subcontinent too. One of the most unique features of Indian Subcontinent and Bangladeshi fashion industry is that though of fashion changes every day but the old trends and styles do not vanish or disappear with time. The old styles in Indian Subcontinent and Bangladeshi fashion clothes disappear for one generation and then flourish again after a few generations.

In the earlier times Indian Subcontinent fashion was primarily restricted to various types of saris and towards the middle of the 20th century there were some variations seen. Today's Indian Subcontinent and Bangladeshi generation is recognized by the trendy Indo Western styles with the effect of Western world fashion. The Indo Western style is a mixture of modernity and traditions of globalization. There is an amalgamation of the salwar (which has been modified into 'Kurti') and the low waist jeans. Another of the traditional Indian Subcontinent and Bangladeshi dresses that symbolizes women is the Sari. Though there have also been many variations or styling in the cuts and designs of the saris but yet this type of clothes has still remained largely similar to the age-old practice. Sari is generally a simple Indian Subcontinent women clothing today are that is worn on special occasions such as weddings and other religious or social festivals. It is a formal procedure or ritual that a woman has to wear a Sari on her wedding day. Saris are made of various types of fabrics and their design in some cases (as with the Benarasi, Jamdani) it is hand woven. Some of the most popular kinds of Indian Subcontinent saris include Benarasi, Kanjeevaram, Bandhej, Chanderi, Chikan, Hakoba, Handloom, Baluchari, Patola, Phulkari and Parsi saris. Where some famous Saris of Bangladesh are are Jamdani, Dhakai, Katan, Rajshahi Silk, Tangail, etc.

However, latest from the market, the saris in vogue nowadays are designer saris, embroidered saris and mirror work saris. These saris are available in varies materials like georgette, chiffon, crepe, silk etc. Moreover, the butterfly pallu saris are also liked by the women, as it gives them a completely hot look. These saris provide full opportunity to flaunt your beauty as they are knotted below bare shoulders. Focusing on blouses, halter necks are quite in. You can even catch a Bollywood beauty in those shimmery halter blouses, giving complex to Venus herself. So, to look traditional yet fashionable put on that trendy sari and get ready to sizzle

\subsection{Cotton Sari:}

\section{Description Of Components Of Sari}

Indian Subcontinent Cotton saris give a pure relaxing comfort. Cotton Saris are the most favored saris for Indian Subcontinent Women. One can use cotton sari in daily wear especially during summer season. Cotton saris can be worn at festive as well as daily wear. Cotton sari is worn at holi, diwali, dussehra, lohri, baisakhi and all the other festivals. Cotton saris are also office wear Saris worn by teachers while going to schools/colleges, lady doctors and housewives in their daily wear.

The famous cotton saris region wise are as follows:

The jamdani cotton Sari from West Bengal and Uttar Pradesh are popular and they follow the traditional patterns.

We have the Sambalpuri, Bomkai and Vichitrapuri cotton saris of Orissa. These saris come in a variety of colors and traditional motifs inspired by nature. Chanderi Saris in Madhya Pradesh are fine cotton sari with a silk warp and cotton weft. Maheshwari saris of Madhya Pradesh are either pure cottons or silk/cotton mix, with check patterns being the specialty.The city of Hyderabad is known for its ancient cotton weaving tradition. The Venkatgiri fine cotton saris are produced here, which are ideal for summers. These saris are mainly in off-white color and decorated with dull golden motifs. Nander in Andhra Pradesh is famous for its fine quality cotton sari richly worked in gold thread with silk border. Pochampalli saris of Andhra Pradesh are woven with the ikat patterns, where the yarn is pre dyed based on pattern before weaving. In Tamilnadu, the cotton sari patterns closely resemble the silk ones. The important centers like Kanjeevaram, Salem, Pudukottai and Madurai. These centers in the South are famous for cotton weaves with motifs \& checks lay on the body. The border \& pallau are worked with thread or Zari weaves. Kerala has started weaving cotton saris of late. Its specialty is the Karalkudi saris of unbleached cotton with rich broad gold borders and pallus. We also have the tie and dye cotton saris from Rajasthan and Gujarat. Women folk painstakingly create these colorful saris, tying every single thread manually and then dying in vibrant and bright colors. There are also other cotton saris like the Ikat saris of Karnataka and the Narayanpet saris of Andhra Pradesh etc. Beside the region wise cotton saris, we also have other varieties of cotton saris like Handloom cotton sari, printed cotton sari, cotton saris with embroidery 
and Zari work. Apart from traditional and contemporary collections of saris for middle and old-aged women, trendy saris for youngsters are available in the Indian Subcontinent Market. We also have handloom or Khadi saris. The traditional Indian Subcontinent cotton weaving revolves around 'Khadi'. Khadi is a cloth woven by hand using handspun yarn only. Handlooms producing Khadi weave cotton in such a way that the interlacing of threads provides maximum passage of air to the body, thus creating a cooling effect, making Khadi an ideal summer wear. Different colors make these cotton saris exciting. Cotton saris give a sophisticated, feminine, graceful and elegant look to any lady.

\subsection{Silk Saris}

Silk saris in Indian Subcontinent are very popular for any kind of occasion. Silk saris are most exotic and sensual. Silk sari is a smart sari fabric. A women's wardrobe is incomplete without a silk Sari. Silk has been a highly revered fabric in Indian Subcontinent. The softness, smoothness, luster and its graceful and sensuous folds of the fabric are marvels for designing silk saris. Silk saris are often created with zari. Silk saris are popular all across Indian Subcontinent for their shine and glamour.

\subsection{Tissue Sari}

Surprisingly affordable and easily maintained, Tissue is woven of $100 \%$ polyester, and is moderately wrinkle resistant, and is machine washable or dry cleanable, depending on color and trim combinations. Tissue offers the ultimate in draping qualities and sumptuous texture. This top quality silky faille weave brings an elegant gracefulness to a sari. There are silk tissues as well as cotton tissue saris. Cotton tissue saris are ideal for summer. Tissue silk is a very fine quality silk fabric. It is a very shiny and gorgeous fabric. Tissue silk sari can be both simple and gorgeous depending on the occasion in which it is worn.

\subsection{Georgette Saris}

Georgette sari is often made up of nylon and polyester. It is the most graceful fabric. When draped properly, it can add charm to the beauty of the lady. It is a very soft and delicate texture that is comfortable, at the same time gives a gorgeous look. It is a party wear which has the most intricate designs. Georgette sari collection is like a treasure. The soft and shimmering georgette sari is widely used as the dress for women. The graceful drape of georgette gets perfectly blended with traditional Indian Subcontinent designs and patterns.

\subsection{Chiffon Saris}

Chiffon sari is yet another sari that makes an elegant wear both for everyday wear and evening wear. These are very fine graceful saris for every occasion. The chiffon fabric is widely used in Indian Subcontinent fashionable saris Chiffon is a plain-weave, lightweight, sheer, transparent fabric made of cotton, silk or synthetic fiber; it is made of fine, highly twisted, strong yarn. Chiffon is difficult to handle, but it drapes and wears well and is very durable despite its light weight. The famous product of its fabric is chiffon sari.

\subsection{Crepe Saris}

Crepe saris are suitable for formal get together and parties. One can wear crepe saris for any occasion but in summer wedding crepe sari gives a modern look. Crepe saris make a woman look and feel attractive. The summer friendly fabrics like georgette saris, lovely chiffon saris and crepe saris are very abstemious saris. Different colors make these crepe saris exciting. Crepe is a thin fabric of crinkled texture, woven originally in silk but now available in all major fibers. Silk crepe is a classic soft fabric with good drape characteristics.

\section{Sari As A Cloth:}

Saris are woven with one plain end (the end that is concealed inside the wrap), two long decorative borders running the length of the sari, and a one to three foot section at the other end which continues and elaborates the length-wise decoration. This end is called the pallu; it is the part thrown over the shoulder in the nivi style of draping.

In past times, saris were woven of silk or cotton. The rich could afford finely-woven, diaphanous silk saris that, according to folklore, could be passed through a finger ring. The poor wore coarsely woven cotton saris. All saris were hand-woven and represented a considerable investment of time or money.

Simple hand-woven villagers' saris are often decorated with checks or stripes woven into the cloth. Inexpensive saris were also decorated with block printing using carved wooden blocks and vegetable dyes, or tie-dyeing, known in Indian Subcontinent as bhandani work.

More expensive saris had elaborate geometric, floral, or figurative ornaments or brocades created on the loom, as part of the fabric. Sometimes warp and weft threads were tie-dyed and then woven, creating ikat patterns. Sometimes threads of different colors were woven into the base fabric in patterns; an ornamented border, an elaborate pallu, and often, small repeated accents in the cloth itself. These accents are called buttis or 
bhuttis (spellings vary). For fancy saris, these patterns could be woven with gold or silver thread, which is called zari work.

Sometimes the saris were further decorated, after weaving, with various sorts of embroidery. Resham work is embroidery done with colored silk thread. Zardozi embroidery uses gold and silver thread, and sometimes pearls and precious stones. Cheap modern versions of zardozi use synthetic metallic thread and imitation stones, such as fake pearls and Swarovski crystals.

In modern times, saris are increasingly woven on mechanical looms and made of artificial fibers, such as polyester, nylon, or rayon, which do not require starching or ironing. They are printed by machine, or woven in simple patterns made with floats across the back of the sari. This can create an elaborate appearance on the front, while looking ugly on the back. The punchra work is imitated with inexpensive machine-made tassel trim.

Hand-woven, hand-decorated saris are naturally much more expensive than the machine imitations. While the over-all market for hand weaving has plummeted (leading too much distress among Indian Subcontinent hand weavers), hand-woven saris are still popular for weddings and other grand social occasions.

\subsection{Casual:}

\section{Sari As A Dress}

Sari is mostly used as casual or daily wear in the whole part of Indian subcontinent. Women of all walk of life are using Sari as their clothing for house hold works, their chores, caring of family members, and even their evening or sleeping wears.

\subsection{Weddings}

Weddings have great importance in Indian Subcontinent and are celebrated with much joy and gaiety. In celebration dress held great prominence as it reflects inner joy of a person. Women generally wear sari in weddings. Even teenager girls love wearing saris. For weddings saris are ample in variety with fabrics, colors, designs and styles. Richly embellished saris are greatest choice of women for weddings. Apart from it the traditional silk saris, gold zari decked saris, cut work saris, patch work saris, embroidered saris etc. are largely worn. Red, maroon, blue, purple, gold, green etc. are popular wedding sari colors. Black and white color sari should be avoided as these colors are looked upon as inauspicious in Indian Subcontinent. Georgette, silk, chiffon, sati and polyester are favorite fabrics for wedding saris. In styles it is completely up to personal choice what women want to opt for. Options are myriad in wedding saris for women.

\subsection{Formal}

Right definition for formal saris is the one that imparts smart and sophisticate look to women. Cotton saris fulfill these requirements to the best possible manner, thus perfect for wearing to formal places. Cotton saris can also have print over them. Light color or pastel color cotton saris should be worn to formal events. Sari is the most appropriate wear for offices and looks elegant.

\subsection{Evening Parties Saris}

Saris for evening party are the glamorous ones. They are very stylish, chic and elegant to look at. They make entire appearance shine, such is their glamour. Saris that are latest in fad for evening party are fish cut saris, mermaid style saris; lehnga style saris etc.

\subsection{Simple Get Together}

Get together parties are semi formal events. They can be held between families, friends or colleagues anyone. There are separate sari styles for women for semi formal occasions as saris for these occasions cannot be either completely formal or casual or very glamorous. Your appearance should be simple yet elegant. Wear your best sari to these occasions. Women can do experiment with colors, styles, designs, necklines and sleeve lengths in semi formal occasions. Main thing is your sari should ooze out confidence and attitude. So select the one you are comfy in.

\section{Conclusion:}

Sari is the dress of old civilization as its appeal-it remains same in the society of Indian Subcontinent. However, women are wearing much three piece dresses for their easy movement and convenience for work, sari is still unparallel to the society regarding its popularity or acceptability. Nothing can in fact make the displacement sari due to many factors working here. 


\section{Bibliography}

[1]. Altekar, Anant Sadashiv (1956). The Position of Women in Hindu Civilization, Motilal Banarsidass Publisher

[2]. Bhuiyan, Zafar Alam (2014): Sari-the oldest drape art of the world, Master's Paper, MA in Fashion Design, Shanto-Mariam University of Creative Technology, Bangladesh

[3]. MacClaud, Peter (2006): Past and Present Trends in Fashion Technology, Bharat Bhushan, Abhishek Publications, Chandigarh-17, India

[4]. Palm Beach Daily News: "Indian Sari Comes West to American Women", 9 November 1964. Retrieved 20 March 2012

[5]. Sachidanand, Sahay (1975): Indian costume, coiffure, and ornament, Munshiram Manoharlal publishers Pvt Ltd. 